\title{
Portfolio screening to support the mainstreaming of adaptation to climate change into development assistance
}

Klein, R.T.J, Eriksen,S.E.H., Næss,L.O., Hammill, A., Tanner Thomas, Robledo, C. and O'Brien, K.L

AAM version, please cite as

Klein, R.T.J, Eriksen,S.E.H., Næss,L.O., Hammill, A., Tanner Thomas, Robledo, C. and O'Brien, K.L (2007) Portfolio screening to support the mainstreaming of adaptation to climate change into development assistance. Climatic Change, 84: 23-44

\begin{abstract}
Summary
The need to mainstream adaptation to climate change into development planning and ongoing sectoral decision-making is increasingly recognised, and several bilateral and multilateral development agencies are starting to take an interest. Over the past years at least six development agencies have screened their project portfolios, generally with two goals in mind: $(i)$ to ascertain the extent to which existing development projects already consider climate risks or address vulnerability to climate variability and change, and (ii) to identify opportunities for incorporating climate change explicitly into future projects. As each portfolio screening was conducted independently, the broader lessons emerging from the screenings have not been systematically analysed.

In this paper we assess the screening activities to date, focusing on both the results and the methods applied. Based on this assessment we identify opportunities for development agencies to expand their current focus on the links between climate and development. Most agencies already consider climate change as a real but uncertain threat to future development, but they have given less thought to how different development patterns might affect vulnerability to climate change. The screenings undertaken have shown the need to take a comprehensive approach to adaptation and its integration into development planning and sectoral decision-making, and a number of policy initiatives have been taken to promote such integration. We provide some initial guidance as to how portfolio screening can be carried out in a way that would allow agencies to assess systematically the relevance of climate change to their ongoing and planned development projects.
\end{abstract}




\section{Introduction}

Links between climate change and development are becoming increasingly apparent. There is now little doubt that climate change is happening and that it is largely caused by humaninduced greenhouse gas emissions. These emissions are driven by socio-economic development patterns characterised by economic growth, technology, population and governance. At the same time these patterns also influence people's vulnerability to the impacts of climate change, which will in turn influence socio-economic development and thereby future greenhouse gas emissions.

The links between greenhouse gas emissions, mitigation of climate change and development have been subject of intense study (for an overview see Markandya and Halsnæs, 2002). More recently the links between adaptation to climate change and development have been

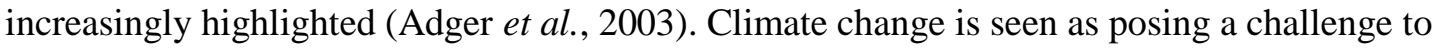
meeting important development objectives and adaptation should be consistent with development priorities (e.g., Sperling, 2003). To consider climate change in development activities could add a long-term sustainability component to official development assistance (ODA). Specifically, there are three ways in which adaptation to climate change is relevant to ODA projects (Klein, 2001):

- The risk of climate change to the ODA project and its deliverables (such as water supply, infrastructure, food security, human health, natural resources management and protection against natural hazards);

- The vulnerability to climate change of the community or ecosystem that is intended to benefit from the ODA project;

- The possible effects of the ODA project and its deliverables on the vulnerability of communities or ecosystems to climate change.

Recent research and policy initiatives have moved adaptation from being the "handmaiden to impacts research in the mitigation context" (Burton et al., 2002) to an activity that is considered crucial within the broader context of sustainable development. The link between adaptation and development is particularly relevant when seeking to enhance the capacity of people and communities to adapt to climate change. This adaptive capacity is often limited by a lack of resources, poor institutions and inadequate infrastructure, amongst other factors that are typically the focus of ODA (Smith et al., 2003). Vulnerability to climate change can therefore be reduced not only by mitigation of greenhouse gas emissions and by adaptation to the impacts of climate change, but also by development aimed at improving the living conditions and access to resources for those experiencing the impacts, as this will enhance adaptive capacity.

The World Summit on Sustainable Development (Johannesburg, August/September 2002) provided a strong impetus to the discourse supporting links between climate policy and development. It has given rise to exploring and developing the concept of "mainstreaming". Mainstreaming involves the integration of policies and measures that address climate change into development planning and ongoing sectoral decision-making, so as to ensure the longterm sustainability of investments as well as to reduce the sensitivity of development activities to both today's and tomorrow's climate (Klein, 2002; Huq et al., 2003; Agrawala, 2005). The concept has been borrowed from development discourses, where the mainstreaming of gender issues has long been understood as an effective way of ensuring gender equity in development policies. By its very nature, energy-based mitigation (e.g., fuel switch and energy conservation) can only be effective when mainstreamed into energy policy. For adaptation, however, this link has not appeared as self-evident until recently.

Mainstreaming entails making more efficient and effective use of financial and human resources rather than designing, implementing and managing climate policy separately from 
ongoing activities. As discussed in more detail in Section 2 of this paper, prospective efficiency and effectiveness gains provide a rationale to development agencies for analysing the potential for mainstreaming in their development activities. Over the past years at least six development agencies have taken the initiative to screen their portfolios of development activities, generally with two goals in mind: $(i)$ to ascertain the extent to which existing development projects already consider climate risks or address vulnerability to climate variability and change, and (ii) to identify opportunities for incorporating climate change explicitly into future projects.

As each portfolio screening was conducted independently, the broader lessons emerging from these portfolio screenings have not been systematically analysed. By providing such an analysis, we aim to contribute to the understanding of mainstreaming of climate change adaptation into ODA. Section 3 assesses the screening activities to date, focusing on both the results and the methods applied. Section 4 outlines recent policy developments that have taken place in response to new insights regarding mainstreaming adaptation. Portfolio screening is intended to allow agencies to assess systematically the relevance of climate change and adaptation to their current and future portfolios of development projects, guidance for which is presented in section 5. In section 6 we conclude that the emerging need for a comprehensive approach to mainstreaming has implications both for how a screening is carried out and how it is embedded institutionally within development agencies.

\section{Why Portfolio Screening?}

By portfolio screening we mean the systematic examination of an agency's set of policies, programmes or projects, with the aim of identifying how concerns about climate change can be combined with an agency's development priorities, such as poverty reduction, institutional development and capacity building. A portfolio screening can identify opportunities for the mainstreaming of adaptation to climate change into ODA at the national, subnational and local levels. In this section we discuss how adaptation to climate change is increasingly recognised as involving not only the implementation of technological measures but also includes consideration of non-technical and non-climate issues. We then argue that the mainstreaming of adaptation into ODA needs to reflect this more comprehensive view on adaptation and highlight the challenges posed to portfolio screening efforts by such an approach.

Mainstreaming can achieve two things. First, it can contribute to the climate proofing of existing projects; that is, it can modify existing projects to ensure that they are no longer at risk from climate change or no longer contribute to the vulnerability of its recipients. Second, and perhaps more importantly, mainstreaming can ensure that future projects and strategies are consciously aimed at reducing vulnerability by including priorities that are critical to successful adaptation, such as ensuring water rights to groups exposed to water scarcity during drought. The second type of mainstreaming has implications for the formation of development priorities and projects themselves.

The traditional view of adaptation tends to assume that a national government develops and implements technological adaptation measures (e.g., dams, early-warning systems, seeds and irrigation schemes) based on specific knowledge of future climate conditions (e.g., Carter et $a l ., 1994)$. In this traditional view mainstreaming would largely refer to ensuring that projections of climate change are considered in the decision making of relevant government departments and agencies, so that technologies are chosen that are suitable to the future climate. For example, water managers would fit a drainage system in an area projected to experience more intense rainfall events with bigger pipes when replacing old ones, and agricultural extension services concerned about the possibility of increased drought would advise farmers to select crop varieties that are better suited to grow under dry conditions.

However, the traditional view of adaptation is being challenged for three reasons (e.g., 
Smithers and Smit, 1997; Burton et al., 2002; Adger et al., 2003; Smith et al., 2003). First, the uncertainties surrounding the manifestation of climate change often make it difficult to project the extent and future impacts of climate change in sufficient detail to justify investment in technological adaptation measures, in particular on a local scale. An important uncertainty relates to the effect of a changing climate on the frequency, magnitude and spatial occurrence of extreme weather events, such as floods, cyclones and droughts. Planning specific measures based on projections of future climate conditions therefore presents a great challenge to developing countries.

Second, technological adaptation measures can be important in reducing vulnerability to climate change, but they do have their limitations. Three issues need to be considered here:

- Technological adaptation measures may be only partially effective if they do not address non-climate factors that contribute to vulnerability to climate change;

- Technological adaptation measures may be ineffective if they are not suited to local conditions;

- Technological adaptation measures may turn out to be maladaptive if they are implemented without recognition of relevant social and environmental processes.

The extent to which people and communities are vulnerable to climate change depends in part on the magnitude and rate of climate change and its consequent impacts but also on their adaptive capacity. As mentioned earlier, adaptive capacity can be constrained by a lack of resources, poor institutions and inadequate infrastructure, amongst other factors. In many cases vulnerability to climate change may be reduced more effectively and comprehensively by addressing these non-climate factors than by implementing a technology that is aimed at a particular impact of climate change but which has no further development benefits. For example, the technological improvement of a water supply system to ensure the availability of water during dry spells will be of limited benefit to people who do not obtain access to this water. The inequitable distribution of water rights or the price of the water may be more important factors in causing vulnerability to drought than deficient water supply technology.

In the traditional view of adaptation, adaptive capacity would refer to the ability of a national government to develop and implement technology-based adaptation measures. However, adaptation is primarily a local process, which means that technologies need to be suited to local conditions to be effective and that local capacity must be developed to use and maintain the technology. One cannot assume that a technology that has been effective in reducing vulnerability to climate change in one location will have the same effect when transferred to another location without considering the differences between these locations and without complementing the technology transfer with training and capacity building. In addition, the local context determines to what extent a technology would be suitable for a particular purpose. For example, new drought-resistant crop varieties may indeed be very resistant to drought, but their acceptance in a community also depends on their costs and availability, access to fertiliser and other inputs, storage constraints, ease of preparation, flavour and so on.

Technological adaptation measures, whilst reducing the vulnerability to climate change of some people, may unintentionally increase the vulnerability of others. For example, new coastal infrastructure could disturb the offshore sediment balance, resulting in erosion in adjacent coastal areas. Irrigation can lead to the salinisation of groundwater and the degradation of wetlands, as well as leaving subsistence farmers with reduced access to groundwater and productive land (Gupta and Abrol, 2000; Zhou et al., 2006; Davis, 2006). Such maladaptation, which often affects those with little power and limited access to resources, could be avoided by recognising and seeking to understand the relevant social and environmental processes that govern the system in which the technology is implemented (Klein et al., 2006). 
Third, the traditional view of adaptation to climate change does not consider the links between adaptation to climate change and development. People are vulnerable not only to climate change but to a range of other stresses, depending on factors such as access to resources and other socio-environmental circumstances shaped by political and economic processes (Kelly and Adger, 2000; O'Brien et al., 2004). Technological measures designed to adapt to specific changes in climate may therefore fail to address the issues considered as most urgent by local communities. These issues may include access to water and food, health and sanitation, education and livelihood security. The Millennium Development Goals (MDGs) prioritise these and other issues and have become guiding principles for ODA.

The above leads us to conclude that the mainstreaming of adaptation should not be restricted to incorporating, for example, the need for bigger pipes and drought-resistant crops into ongoing plans and activities, but instead take a comprehensive approach to adaptation and its integration into development planning and sectoral decision-making. A mainstreamed adaptation strategy should include measures that address the underlying factors of vulnerability to climate change, particularly on a local scale. These underlying factors are often structural issues characterising low development, such as high dependence on natural resources, resource degradation, inability to secure basic needs and lack of information and capacity (Sperling, 2003). If technological measures are required to reduce vulnerability to climate change, they need to be accompanied by non-technical measures (e.g., training and capacity building, institutional support) that ensure that the technologies are accessible, effective and suited to local conditions. A multitude of local coping strategies exist that people use to manage their natural resources and secure their livelihoods in a variable climate (Adams et al., 1998; Adger and Kelly, 1999). These coping strategies can play a crucial part in adapting to climate change as well.

In view of the need to develop local capacity and to consider the links between adaptation to climate change and development, development agencies would be well placed to initiate the mainstreaming of adaptation, in particular if there are synergies between adaptation and development priorities such as the MDGs, the first one of which is to eradicate extreme poverty and hunger. If such synergies exist, adaptation can be mainstreamed into development activities without much extra effort. The design and implementation of adaptation measures can benefit from the experience of decades of development work, including the realisation that measures targeting local needs are more likely to be successful than large-scale measures implemented through a top-down approach (e.g., Adger et al., 2003; Orindi and Eriksen, 2005). A comprehensive approach to adaptation therefore involves considering which, or how, development priorities such as those guided by the MDGs can best target the underlying causes of vulnerability.

Such an approach presents two new challenges to mainstreaming. First, a recipient country's objectives are supposed to guide the selection of development priorities pursued by a donor agency. Adaptation to climate change may not be highly prioritised by the recipient country, and some development objectives, such as privatisation of resource rights, may even be in conflict with efforts to reduce the vulnerability of the poor. On the other hand, it has been pointed out that development agencies' awareness of climate change can be important in dialogues with the recipient country on priority interventions to be supported (Ulsrud and Eriksen, 2006).

Second, poverty reduction does not always equate with vulnerability reduction (Adger et al., 2003; Eriksen and Kelly, 2005). In these cases synergies between adaptation and development priorities may not exist. There are well-documented cases of projects aimed at reducing poverty that have in fact increased vulnerability. For example, the conversion of mangroves into shrimp farms may generate economic gains but leave coastal communities more vulnerable to coastal hazards such as storm surges (Adger et al., 2001). New roads in developing countries often affect settlement patterns; even if a new road were constructed so 
as to withstand climate change it is equally important to consider whether or not it would attract new settlers to areas exposed to natural hazards (Agrawala et al., 2003a). Robledo and Forner (2005) presented additional examples of how development strategies may increase the vulnerability of natural and social systems to climate change. If conflicts arise between poverty reduction and vulnerability reduction, adaptation would involve designing and implementing measures that are more targeted to specific threats than development activities tend to be. Mainstreaming can then ensure that development activities themselves are not maladapted to climate change. However, this demands a relatively high level of understanding of the complex societal processes that generate vulnerability and poverty.

The impetus for portfolio screening to support mainstreaming has been reinforced through policy commitments and political declarations. Industrialised countries have agreed broad commitments to provide financial resources to developing countries under articles 4.3, 4.4, 4.5, 4.8 and 4.9 of the UNFCCC. In 2001 a number of countries, including EU member states, signed a declaration agreeing to minimum levels of additional funding for climate change adaptation activities3. This includes funding via contributions to the Global Environment Facility (GEF), adaptation actions through additional ODA, and contributions to the then newly established funds under the UNFCCC and Kyoto Protocol to facilitate adaptation in developing countries. In 2006 the OECD Development Assistance Committee (DAC) and the Environment Policy Committee (EPOC) launched a process to work in partnership with developing countries to integrate environmental factors efficiently into national development policies and poverty reduction strategies. OECD member states agreed on a Framework for Common Action Around Shared Goals, as well as a Declaration on Integrating Climate Change Adaptation into Development Co-operation (OECD, 2006).

These commitments and declarations have provided a strong imperative to mainstream adaptation into ODA. First, dependence only on specific adaptation funds is likely to fall magnitudes short of the estimated costs of adaptation (World Bank, 2006; Stern, 2007).

Second, providing finance via specific funds entails the technical, scientific and institutional challenges of tackling additional climate change impacts rather than those from existing variations in climate (Klein, 2003; Burton and van Aalst, 2004b). Third, separation of funding sources weakens the potential for efficiency and effectiveness gains associated with the mainstreaming of adaptation as outlined earlier in this section (Mitchell and Tanner, 2006). Whilst projects implemented with these funds are likely to provide important foundations and lessons, tackling future climate-related risks to development requires a more comprehensive approach. This recognition has motivated a range of donor agencies to conduct screenings of their programme and project portfolios.

\section{Portfolio Screening Efforts to Date}

Section 2 identified the need for a comprehensive approach to adaptation, that is, for mainstreaming to address a range of stressors and underlying causes of vulnerability in addition to technological adaptation measures. This section investigates the implications of such an approach for portfolio-screening methods. We assess portfolio-screening efforts commissioned to date by the following six agencies: the World Bank (Burton and Van Aalst, 1999, 2004a,b), the German Technical Co-operation Agency (GTZ; Klein, 2001; Kasparek, 2003), the Organisation for Economic Co-operation and Development (OECD; Agrawala 2005), the Norwegian Agency for Development Co-operation (Norad; Eriksen and Næss, 2003), the Swiss Agency for Development and Co-operation (SDC; Robledo et al., 2006), and the UK Department for International Development (ERM, 2002; DFID, 2004)1. With the exception of DFID, whose activities are ongoing, each of these organisations has made the results of its portfolio screening available to the public. We first describe the aims, activities, scope, findings and recommendations of the six screenings so as to identify challenges for the mainstreaming of adaptation. We then compare methods used for the screenings, focusing at 
their ability to identify and meet particular challenges for mainstreaming. As the portfolio screenings were carried out independently of one another, they can be seen as pilot efforts informing how future screenings could be carried out, as discussed in Section 5.

Burton and Van Aalst (1999) conducted a review of climate change considerations in World Bank operations, examining six projects and six countries (Bangladesh, Guyana, India, Papua New Guinea, Ecuador and Samoa). The projects and countries were selected so as to "(...) illustrate a wide range of situations both with respect to the nature of climate risks and the level of development, as well as regional diversity" (p. v). The aim was to examine implications of climate change for World Bank operations. Three issues were given particular emphasis: (i) the vulnerability of projects to climate change, (ii) the impacts of projects on vulnerability, and (iii) implications of institutional roles within the UNFCCC and GEF for the World Bank's activities. The projects were examined on the basis of whether and how they discussed climate risk, "[comparing] the project reports with known climate risks facing the project or the country" (p. 11). The country review discussed criteria for assessing climate exposure vis-à-vis climate change, the sensitivity of the World Bank's portfolio to climate change and the coverage of climate change in the Country Assistance Strategies (CAS). Burton and Van Aalst (1999) found that climate risks were not well assessed at the project level. Climate risks were rarely mentioned in the project documents, even in areas with high current climate risks such as floods and cyclones. Interestingly, climate risks often emerged in implementation documents, which the authors suggest is because climate is "seen as a risk to project implementation rather than to long-term sustainable operation" (p. 12). In the countries reviewed, climate change was not discussed at all within the CAS.

Klein (2001) reviewed German-funded ODA projects in Africa within the area of natural resources management, with the aim of (i) identifying to what extent projects already considered the risk of climate change, as well as opportunities for adaptation, (ii) exploring opportunities to incorporate adaptation to climate change in future projects, and (iii) providing a starting point for awareness raising on the needs and opportunities for adaptation amongst government staff. A total of 136 projects were reviewed in order to establish whether or not they considered climate change or weather and climate-related stresses in their project documents. None of the project documents referred explicitly to climate change, and attention to weather and climate-related stresses was found to be low and primarily reactive. Five projects were selected for in-depth review of project documents and interviews with project managers. These projects were selected on the basis of their no-regret adaptation potential and their opportunities for generating secondary benefits (i.e., benefits not related to the primary purpose of the project). The in-depth review showed that climate change consideration was lacking even in areas where climate factors posed obvious risks today. Project staff indicated that climate change was not seen as relevant to immediate concerns such as health and clean water, and some considered it an "unnecessary burden on their projects" (p. 30). The study concluded that "[the] limited consideration of climate-related stress is striking in light of the intricate balance between the productivity of Africa's natural resources and prevailing climate conditions" (p. 9). A follow-up to the report involved a questionnaire survey for agency staff (Kasparek, 2003). It confirmed that climate change was hardly discussed in project preparation, but at the same time it revealed that a majority of agency staff would like to have more information and support to integrate adaptation to climate change in their work.

A review by Eriksen and Næss (2003) for the Norwegian Agency for Development Cooperation (Norad) aimed at reviewing links between Norwegian development co-operation and adaptation to climate change, identifying entry points at the strategic and operational level, as well as recommending strategies for future integration. Overall, the direct reference to climate change in development policies and strategies was found to be negligible and largely framed as a mitigation concern. For example, Norway's poverty reduction action plan under the MDGs only mentions climate change in relation to the country's moral obligation towards developing countries for the responsible management of the climate as a global 
public good. No further details are given on what this might mean in practice. The review did not look at specific programmes or projects, but feedback from senior staff suggests that there had as yet been little or no discussion of climate change in relation to Norad's work. The report identified a number of areas where climate change could be integrated without any major changes to current goals or working modes. As this review examined policies and strategies, it engaged staff at the Norad head office, but there was no direct involvement of agency staff on the ground.

DFID piloted portfolio screening in its Bangladesh office, using a process-based methodology called ORCHID (Opportunities and Risks of Climate Change and Disasters; Tanner et al, 2007). The approach combined attention to current disasters with tackling impacts of climate change and sought both to manage specific risks and to enhance broader opportunities for reducing vulnerability. Previously, climate change adaptation issues were rarely picked up in environmental screening procedures or project risk assessments. The new strategic country assistance now prioritises reducing vulnerability to disasters and climate change, but may need to tackle transboundary as well as domestic issues. The screening prioritised ten ongoing and future DFID-funded programmes, and options for adaptation and disaster risk reduction were assessed for integration into the portfolio. Results reinforced the contribution that many programmes already make to vulnerability reduction and a formalised screening approach was able to focus this further. The screening also revealed the need for improved vulnerability assessment at the local level. Few projects were found to manage actively current disaster risks, despite regular disaster events in Bangladesh. Assessing future risks provided an important impetus to tackle this current deficit, especially in infrastructure development. Staff were involved through the assessment of project options. From an initially low level, rapid increases in awareness and action were underpinned by internal publicity (DFID, 2004), highlevel championing during the UK's 2005 Presidencies of the EU and G8, and the prioritisation in a recent UK White Paper (DFID, 2006).

The Development and Climate Change project of OECD sought to identify synergies and tradeoffs involved in mainstreaming climate change in development assistance. Amongst other activities, the project carried out country case studies in Bangladesh, Egypt, Fiji, Nepal, Tanzania and Uruguay, with a focus on adaptation (Agrawala, 2005). The studies identified key priorities for adaptation on the basis of assessments of recent trends, climate change scenarios and potential sectoral impacts. In addition, donor portfolios were analysed for the proportion of projects affected by climate risks, and the studies conducted in-depth analyses of key resources potentially affected by climate change. Amongst the findings were that climate risks and climate change are largely missing in project documents, although a large share was considered to be affected by climate risks (typically $20-30 \%$ or more of the monetary value and number of projects). In Bangladesh it was found that climate change had been given a "fair degree of interest" by sectoral planners (Agrawala et al., 2003b, p. 28). However, attention to climate change was largely absent in higher-level policy documents, including the World Bank's CAS. Key recommendations from the case studies were that $(i)$ adaptation should be part of the "core development activity" (i.e., funded as part of ODA) rather than financed under the international climate policy regime, and (ii) the focus of adaptation should move beyond improving the ability to adapt to current weather extremes and climate variability (Agrawala, 2005).

Robledo et al. (2006) conducted an assessment of the potential effects of projects and programmes financed by the Swiss Agency for Development and Co-operation (SDC) on vulnerability to climate variability and change, based on an inventory of issues by SDC (2005)2. This assessment was based on the thesis that previous projects in natural resource management could have had unintended positive effects regarding both mitigation and adaptation, as well as promoted the conservation of biological diversity. The assessment addressed three levels: (i) understanding and preparedness at the national level, (ii) impacts and vulnerability at the local level, and (iii) main barriers to the implementation of mitigation 
and adaptation measures. Robledo et al. (2006) identified three different ways in which adaptation could be mainstreamed: thematic, methodological and related to the implementation of concrete measures. In addition, they identified three thematic areas in which action is considered necessary: institutional development for adaptation, the role of technology transfer in adaptation and capacity building for adaptation. At the methodological level Robledo et al. (2006) identified the need to improve climate forecasting at the local level. In addition, the report recommended investing efforts in the development of tools to plan adaptation measures as a key element of development projects and programmes. Finally, they suggest that pilot projects to implement adaptation measures focus on both the natural and the social system and encourage the empowerment of local communities.

Analysis of the six screenings reveals a number of challenges for identifying effective options to support the mainstreaming of adaptation into ODA. Findings from the different screenings show many similarities (Table 1). For example, all screenings concluded that current attention to climate change in the respective agencies' development policies, projects and programmes was low, which could have negative impacts on development. Importantly, it was found that the agencies had made few or no links to climate change even in areas where climate is already posing considerable risks and where comparatively small changes could have potentially large impacts. In addition to the direct impact of climate change on projects, the omission could also adversely affect vulnerability reduction. Agrawala et al. (2003d, p. 27) noted in the case of Nepal that "(...) some opportunities for vulnerability reduction may well be missed" by not considering climate change. Another common finding was that a link to poverty reduction was missing: where mentioned, climate change was mainly framed as a question of mitigation and largely as an environmental issue, not as a development concern.

The lack of attention to climate change was also reflected in staff attitudes to climate change described by Klein (2001). Whilst there seemed to exist a broad consensus at the policy level in support of mainstreaming adaptation into ODA, attitudes at the project level ranged from a lack of awareness of what mainstreaming would mean in practice to scepticism about an issue not seen as part of the agency's normal mandate or even related to development priorities. Climate change continues to be the responsibility of environment departments in development agencies (which also commissioned most of the screenings to date). Only the GTZ and the DFID screenings included local staff involvement, which could be an important way to improve awareness across sectors within agencies. 
Table 1 Overview of publicly available portfolio-screening efforts to date

\begin{tabular}{|c|c|c|c|c|c|c|}
\hline $\begin{array}{l}\text { Agency } \\
\text { (references) }\end{array}$ & Main goals & Activities & Scope & $\begin{array}{l}\text { Main } \\
\text { methods }\end{array}$ & Key findings & $\begin{array}{l}\text { Recommendations on } \\
\text { mainstreaming }\end{array}$ \\
\hline $\begin{array}{l}\text { World Bank } \\
\text { (Burton and } \\
\text { Van Aalst } \\
1999 ; \\
2004 a, b)\end{array}$ & $\begin{array}{l}\text { Examine what } \\
\text { climate change } \\
\text { would mean to } \\
\text { World Bank } \\
\text { operations }\end{array}$ & $\begin{array}{l}\text { - Projects assessed for } \\
\text { whether and how they } \\
\text { discussed climate risks } \\
\text { - Countries assessed for } \\
\text { range of climate risk } \\
\text { criteria, sensitivity of } \\
\text { portfolio and climate } \\
\text { change coverage in } \\
\text { CAS }\end{array}$ & $\begin{array}{l}\text { - Six selected } \\
\text { World Bank } \\
\text { projects } \\
\text { - World Bank } \\
\text { assistance to six } \\
\text { selected } \\
\text { countries }\end{array}$ & $\begin{array}{l}\text { Document } \\
\text { review }\end{array}$ & $\begin{array}{l}\text { - Little or no attention to } \\
\text { climate change at } \\
\text { project level, even } \\
\text { where climate risks are } \\
\text { obvious today } \\
\text { - Climate seen as a risk } \\
\text { to project } \\
\text { implementation, not } \\
\text { long-term sustainable } \\
\text { development } \\
\text { - No mention of climate } \\
\text { change in CAS }\end{array}$ & $\begin{array}{l}\text { - Knowledge base for } \\
\text { climate risk } \\
\text { management and a } \\
\text { routine screening tool } \\
\text { for projects }\end{array}$ \\
\hline $\begin{array}{l}\text { GTZ (Klein } \\
2001 \text {; } \\
\text { Kasparek } \\
2003 \text { ) }\end{array}$ & $\begin{array}{l}\text { - Identify current } \\
\text { consideration of } \\
\text { climate change, } \\
\text { opportunities for } \\
\text { integration in } \\
\text { future projects } \\
\text { and awareness } \\
\text { raising } \\
\text { - Identify } \\
\text { relevant sectors } \\
\text { and priority } \\
\text { measures for } \\
\text { adaptation }\end{array}$ & $\begin{array}{l}\text { - Projects selected on } \\
\text { basis of potential for no- } \\
\text { regrets and secondary } \\
\text { benefits } \\
-136 \text { projects reviewed } \\
\text { for whether or not they } \\
\text { considered climate } \\
\text { change } \\
\text { - In-depth review of } 5 \\
\text { projects; documents and } \\
\text { interviews staff } \\
\text { - Questionnaire to } 330 \\
\text { ongoing projects }\end{array}$ & $\begin{array}{l}\text { - GTZ project } \\
\text { portfolio on } \\
\text { natural resource } \\
\text { management in } \\
\text { Africa } \\
\text { - Ongoing GTZ } \\
\text { projects in } \\
\text { climate-relevant } \\
\text { sectors } \\
\text { worldwide }\end{array}$ & $\begin{array}{l}\text { Document } \\
\text { review } \\
\text { - Interview } \\
\text { with staff } \\
- \\
\text { Questionn } \\
\text { aire survey } \\
\text { to project } \\
\text { staff }\end{array}$ & $\begin{array}{l}\text { - No explicit } \\
\text { consideration of climate } \\
\text { change in } 136 \text { projects, } \\
\text { also in areas with high } \\
\text { current climate risks } \\
\text { - Climate change not } \\
\text { seen as important issue } \\
\text { by project staff } \\
\text { - Increasing interest in } \\
\text { information on and } \\
\text { support for adaptation } \\
\text { and mainstreaming }\end{array}$ & $\begin{array}{l}\text { - Integrate indicators to } \\
\text { evaluate climate } \\
\text { adaptation in current } \\
\text { routines for project } \\
\text { design, identifying } \\
\text { options that give } \\
\text { immediate benefits and } \\
\text { increase future } \\
\text { flexibility } \\
\text { - Analyse the adaptive } \\
\text { effects of current } \\
\text { projects } \\
\text { - Develop guidance to } \\
\text { consider climate } \\
\text { change in the } \\
\text { development of } \\
\text { projects }\end{array}$ \\
\hline $\begin{array}{l}\text { Norad } \\
\text { (Eriksen and } \\
\text { Næss 2003) }\end{array}$ & $\begin{array}{l}\text { Assess current } \\
\text { level of climate } \\
\text { change } \\
\text { consideration, } \\
\text { identify links } \\
\text { between climate } \\
\text { and } \\
\text { development } \\
\text { and recommend } \\
\text { future strategies }\end{array}$ & $\begin{array}{l}\text { - Review of policy } \\
\text { documents for } \\
\text { development co- } \\
\text { operation, overall and } \\
\text { within key priority } \\
\text { sectors }\end{array}$ & $\begin{array}{l}\text { Norad policies } \\
\text { and strategy } \\
\text { documents }\end{array}$ & $\begin{array}{l}\text { Document } \\
\text { review }\end{array}$ & $\begin{array}{l}\text { - Negligible references } \\
\text { to climate change. } \\
\text { - Where mentioned, } \\
\text { climate change framed } \\
\text { as a mitigation issue } \\
\text { - Many potential entry } \\
\text { points }\end{array}$ & $\begin{array}{l}\text { - Detailed review of } \\
\text { tools currently in use } \\
\text { for project development } \\
\text { and approval in order } \\
\text { to identify ways to } \\
\text { achieve synergies } \\
\text { between climate } \\
\text { adaptation and poverty } \\
\text { reduction }\end{array}$ \\
\hline $\begin{array}{l}\text { SDC } \\
\text { (Robledo et } \\
\text { al. 2006) }\end{array}$ & $\begin{array}{l}\text { Assessment of } \\
\text { potential effects } \\
\text { of projects and } \\
\text { programmes on } \\
\text { vulnerability and } \\
\text { adaptation }\end{array}$ & $\begin{array}{l}\text { - Review of } \\
\text { understanding and } \\
\text { preparedness at the } \\
\text { national level; impacts } \\
\text { and vulnerability at the } \\
\text { local level and main } \\
\text { barriers to implement } \\
\text { mitigation or adaptation } \\
\text { measures }\end{array}$ & $\begin{array}{l}14 \text { SDC projects } \\
\text { and programmes } \\
\text { in } 9 \text { countries in } \\
\text { Latin America, } \\
\text { Asia, Africa and } \\
\text { Eastern Europe }\end{array}$ & $\begin{array}{l}\text { Document } \\
\text { review }\end{array}$ & $\begin{array}{l}\text { - Action needed on (i) } \\
\text { institutional } \\
\text { development for } \\
\text { adaptation, (ii) the role } \\
\text { of technology transfer in } \\
\text { adaptation, and (iii) } \\
\text { capacity building for } \\
\text { affected groups } \\
\text { - Need to improve } \\
\text { climate forecasting at } \\
\text { the local level }\end{array}$ & $\begin{array}{l}\text { - Consider adaptation } \\
\text { as a key element in } \\
\text { development co- } \\
\text { operation and } \\
\text { differentiate } \\
\text { recommendations into } \\
\text { three levels: (i) } \\
\text { thematic, (ii) } \\
\text { methodological, and } \\
\text { (iii) concerning } \\
\text { implementation of } \\
\text { adaptation measures }\end{array}$ \\
\hline $\begin{array}{l}\text { DFID (DFID, } \\
2004 \text {; Tanner } \\
\text { et al, 2007) }\end{array}$ & $\begin{array}{l}\text { Management of } \\
\text { climate risks and } \\
\text { opportunities for } \\
\text { bilateral aid } \\
\text { portfolio }\end{array}$ & $\begin{array}{l}\text { - DFID aid portfolio in } \\
\text { Bangladesh assessed } \\
\text { for current and future } \\
\text { climate risks } \\
\text { - Review of DFID } \\
\text { country strategy in } \\
\text { Bangladesh - } \\
\text { Adaptation and risk } \\
\text { options integrated into } \\
\text { screened projects }\end{array}$ & $\begin{array}{l}\text { Initial country } \\
\text { study for DFID } \\
\text { Bangladesh aid } \\
\text { projects. }\end{array}$ & $\begin{array}{l}\text { - } \\
\text { Document } \\
\text { review } \\
\text { - Options } \\
\text { assessmen } \\
\text { t with } \\
\text { project } \\
\text { staff } \\
\text { - Climate } \\
\text { impacts } \\
\text { assessmen } \\
\text { t } \\
\text { - Cost- } \\
\text { benefit } \\
\text { analysis }\end{array}$ & $\begin{array}{l}\text { - Awareness is low but } \\
\text { rising } \\
\text { - Many areas of portfolio } \\
\text { already contribute to } \\
\text { reduced vulnerability } \\
\text { - Climate change } \\
\text { considerations are } \\
\text { crucial for infrastructure } \\
\text { development } \\
\text { - Need improved } \\
\text { vulnerability } \\
\text { assessment at local } \\
\text { level. }\end{array}$ & $\begin{array}{l}\text { - Climate risks need } \\
\text { management as } \\
\text { routine part of donor } \\
\text { project cycle. } \\
\text { - Need for donors } \\
\text { coherence on } \\
\text { international } \\
\text { dimensions } \\
\text { - Greater interaction } \\
\text { and synergies between } \\
\text { disasters and } \\
\text { adaptation } \\
\text { communities. }\end{array}$ \\
\hline
\end{tabular}


At the same time, the screening reports themselves gave little attention to other potentially important factors affecting the ability to mainstream adaptation into ODA. We argued in Section 2 for the need to go beyond a technology-centred approach to adaptation because of scenario uncertainties, limits to technology and the need to consider development priorities. Only Burton and Van Aalst (2004b) discussed explicitly how different views on adaptation could present a barrier to mainstreaming. Distinguishing between a "Convention Perspective" and a "Development Perspective" to adaptation, they note that "[t]he initial dominance of the Convention Perspective may be one reason why Task Managers at the Bank (...) are sometimes hesitant about embracing the notion of climate change adaptation as enthusiastically or as urgently as we would suggest." (p. 40). Further, there is little discussion of the conceptual links between poverty and vulnerability. Whereas it is frequently emphasised that the poorest are the most vulnerable to climate change, none of the screenings to date provide much analysis of the potential synergies and conflicts between poverty reduction and vulnerability reduction. As a result, it remains unclear what new challenges may be associated with climate change and how adaptation could include activities that would differ from ongoing poverty-reduction priorities and activities. In addition, little attention was given to the process by which mainstreaming could take place, beyond references to the need for awareness raising and capacity building on climate change within agencies.

Further insights can be drawn from the methods used, in particular concerning the extent to which different types of portfolio screenings help to address barriers to mainstreaming. The six screenings can be grouped into three types: assessments of agencies' policies and strategies (Norad), assessments of programmes and projects (World Bank, GTZ, SDC, DFID) and country case studies (OECD). However, this is not absolute (e.g., the screening by the World Bank included country reviews and the ones by OECD reviewed projects) but nevertheless provided some general lessons:

- Reviews of policies and strategies provide a good foundation for strategic discussion of links between ODA and climate change across the agency's portfolio and the overall goals for development (Eriksen and Næss, 2003). Such reviews would therefore seem a good way of assessing which development strategies could benefit from opportunitie to reduce vulnerability and which development pathways could lead to maladaptive results. Weaknesses of this type of screening (i.e., one that does not consider programmes or projects) are its lack of links to practical development and the risk of omitting relevant political processes.

- Programme and project reviews yielded the clearest recommendations on how adaptation could be incorporated in practical ODA activities (e.g., Klein, 2001; Tanner et al., 2007). They can also involve local staff and raise awareness more easily. However, this type of screening seems less clear on the strategic choices involved in mainstreaming (e.g., in terms of development priorities and their vulnerability to future climate change).

- Country case studies provided a comprehensive coverage of climate change in relation to the poverty-reduction agenda in the countries concerned (Agrawala, 2005). They also provided the clearest descriptions of country-specific climate change issues, including the social feasibility of various adaptation options. This is also its main weakness, as a country-specific portfolio screening is likely to be less relevant for other areas and countries.

Table 2 summarises the links between key mainstreaming challenges and the three types of portfolio screenings. 
Table 2 Types of portfolio screenings and key challenges for the mainstreaming of adaptation (+++ = high level of attention, $+=$ low/negligible level).

\begin{tabular}{|c|c|c|c|}
\hline Challenges & $\begin{array}{l}\text { Review of policies and } \\
\text { strategies (Norad) }\end{array}$ & $\begin{array}{l}\text { Programme and project } \\
\text { review (World Bank, } \\
\text { GTZ, SDC, DFID) }\end{array}$ & $\begin{array}{l}\text { Country case studies } \\
\text { (OECD) }\end{array}$ \\
\hline $\begin{array}{l}\text { Range of adaptation } \\
\text { options considered }\end{array}$ & ++ & + & ++ \\
\hline Link to political processes & + & + & +++ \\
\hline $\begin{array}{l}\text { Identification of synergies } \\
\text { and conflicts/contradictions } \\
\text { between poverty reduction } \\
\text { and vulnerability reduction }\end{array}$ & ++ & + & +++ \\
\hline $\begin{array}{l}\text { Identification of new } \\
\text { challenges due to climate } \\
\text { change }\end{array}$ & + & + & + \\
\hline $\begin{array}{l}\text { Enabling proactive } \\
\text { strategies }\end{array}$ & ++ & + & ++ \\
\hline $\begin{array}{l}\text { Awareness raising on } \\
\text { climate-development links }\end{array}$ & ++ & +++ & ++ \\
\hline
\end{tabular}

\section{Recent Policy Developments}

Following the six agency screenings described above, political recognition, support and action on mainstreaming adaptation into development assistance has expanded on a number of levels. In the international policy arena, the UNFCCC is increasingly supporting mainstreaming efforts. Whilst Article 4.1(f) of the Convention calls for Parties to take climate considerations into account in their development planning, until recently there was little guidance on how to move forward. In December 2005 in Montreal, the eleventh Conference of the Parties to the UNFCCC (COP-11) adopted a Five-Year Programme of Work on Impacts, Vulnerability and Adaptation to Climate Change, which focuses on two themes: $(i)$ impacts and vulnerability, and (ii) adaptation planning, measures and actions. Programme implementation will take place through specific activities under each theme, and should incorporate the cross-cutting issues of methodologies, data and modelling, and integration into sustainable development. Specific activities relevant to portfolio screening include developing "methodologies and tools for adaptation planning, measures and actions, and integration with sustainable development". Concrete steps towards implementation of the Work Programme were agreed one year later in Nairobi.

The EU Action Plan on Climate Change (EC, 2004) outlines a number of activities organised under four strategic objectives. Mainstreaming adaptation falls primarily under the strategic objective "Raising the policy profile on climate change". Here specific mention is made of the need to raise awareness of climate change within EU development agencies, as well as integrate climate change into EC and Member State policies by building on existing tools (i.e., risk assessments), resources (such as the EU Environmental Integration Manual), processes (e.g., in-country policy reviews and planning) and networks.

The independent Commission for Africa recommended in 2005 that donors make climate variability and climate change risk factors an integral part of their project planning and assessment, by 2008 (Commission for Africa, 2005). This informed the Gleneagles Dialogue on Climate Change, Clean Energy and Sustainable Development, an informal discussion forum for 20 countries with the greatest energy needs, which was launched at the G8 Gleneagles Summit in July 2005. It monitors the implementation of the Gleneagles Plan of Action (G8 Gleneagles Summit, 2005), which is for the most part a series of measures to promote reductions in greenhouse gas emissions. The Plan of Action also acknowledges the 
need for better climate information to facilitate adaptation, particularly in Africa. More central to the issue of mainstreaming, the Plan calls on the World Bank to "develop and implement 'best practice' guidelines for screening their investments in climate sensitive sectors to determine how their performance could be affected by climate risks, as well as how those risks can be managed". The proposed World Bank investment framework on clean energy and development (World Bank, 2006) confirms that "project portfolios need to be reviewed for their vulnerability to climate change", and calls for the development of a systematic approach to screening of public investment for the impacts of climate change. The Gleneagles Plan of Action invites other major multilateral and bilateral agencies to "adopt the World Bank guidelines, or develop and implement similar guidance" (G8 Gleneagles Summit, 2005, p. 10).

In April 2006, Development and Environment Ministers from OECD countries agreed a "Declaration on Integrating Climate Change Adaptation into Development Co-Operation." In addition to recognising the urgency of adaptation, OECD Member Countries declared their commitment to, inter alia, raising awareness on climate change both internally and externally; identifying and using appropriate entry-points for integration, such as country assistance strategies and long-term investment plans; assisting developing countries to integrate climate change adaptation following the principles of the Paris Declaration on Aid Effectiveness; and developing and applying tools to address climate risks in development activities. The OECD itself was invited to develop guidance for integrating climate change adaptation in development co-operation, as well as devise methodologies for monitoring progress on integration. Particular lessons for how screenings are carried out in practice are discussed in the next section.

\section{Guidance for Portfolio Screening}

Development projects vary in size, time scale and focus, ranging from large-scale infrastructural projects and institutional support in the host country to social development activities at the village level. Portfolio screening is intended to give guidance on how to strengthen the extent to which a set of projects address climate change. However, in order to increase the consideration of climate change within individual projects, more specific project screening is required that is suited to the type of project in question. Follow-up activities to the screening experiences described in Section 3 have initially centred on development of project screening.

In Section 1 we mentioned three ways in which climate change is relevant to ODA projects: (i) the risk of climate change to the ODA project and its deliverables, (ii) the vulnerability to climate change of the community or ecosystem that is intended to benefit from the ODA project, and (iii) the possible effects of the ODA project and its deliverables on the vulnerability of communities or ecosystems to climate change. The first of these three considerations is particularly important in view of a project's long-term viability and should be part of its risk assessment before implementation. A project that intends to prevent soil erosion by planting trees is unlikely to be successful in the long run if the trees selected are sensitive to possible changes in one or more meteorological variables. For example, if the trees require more water than is projected to be available as climate changes, the project could fail and investments would not render the desired outcome. Similarly, a project that involves the construction of infrastructure could fail if design standards are not adjusted to reflect changing probabilities of extreme events such as floods, droughts and storms. For example, if a river's peak runoff is projected to increase, a new bridge may be washed away if this increase has not been considered in the design of the bridge. These examples show that climate change is relevant to the cost-effectiveness of ODA projects that are intended to generate benefits over a longer period of time.

The second consideration can have a similar, albeit more indirect, effect on the long-term 
success of ODA projects. For example, a project that intends to develop agriculture in a lowlying coastal area could fail if sea-level rise were to cause increased flooding and eventually permanent inundation of the area. The productivity of the agricultural land would decline, resulting in reactive adaptation: either people would move away to higher areas or measures would be taken to protect the land and its inhabitants from flooding. Both types of adaptation would come at a cost, which shows that climate change is an important factor to determine the cost-effectiveness of ODA projects that invest in vulnerable areas. It is therefore prudent to assess and consider the extent to which communities or ecosystems are vulnerable to climate change before project implementation.

The third consideration reflects the fact that a natural or human system's vulnerability to climate change is in part determined by its interaction with non-climate stresses. As explained in Section 3, changes in existing management practices could both increase and decrease vulnerability to climate change. ODA projects unrelated to climate change may generate secondary benefits that help to reduce climate vulnerability. On the other hand, ODA projects may also unintentionally increase vulnerability to climate change. As mentioned above, new coastal infrastructure could disturb the offshore sediment balance, resulting in erosion in adjacent coastal areas, and irrigation could lead to salinisation of groundwater and affect wetlands. An additional example of maladaptation may include the development of floodplains, which can lead to a reduced buffering capacity for river water and thus to increased peak runoff. An ODA project may affect local access to natural resources, such as forests, or income sources, such as informal business, traditionally used by the poor to survive droughts. Transfer of financial resources and technologies and the creation of new institutional structures, such as development committees, in connection with ODA projects may alter power relations and inequalities, both underlying factors central in generating the social distribution of vulnerability. Determining the extent to which ODA projects would affect a system's vulnerability to climate change, either by producing secondary benefits that reduce vulnerability or by causing maladaptation that increases vulnerability, would be a useful step before the project is implemented.

These three ways in which climate change can be relevant to ODA projects can be addressed through three types of assessment at the project formulation or preparation stage. These types of assessment, which concern the risk of climate change to an ODA project, the vulnerability to climate change of the community or ecosystem to benefit from the project and the project's effect on vulnerability to climate change, are the following:

- Risk assessment: aimed at quantifying the extent to which potential impacts of climate change pose a risk to the cost-effectiveness and other aspects of the viability of a project; - Vulnerability assessment: aimed at evaluating the vulnerability to climate change of the community or ecosystem at which a project is targeted, and the social and economic processes that create vulnerability and which ODA projects may affect;

- Environmental impact assessment: aimed at analysing the extent to which a project would affect, either positively or negatively, a system's vulnerability to climate change.

The latter type of assessment only addresses the vulnerability of an environmental system; analysis of the extent to which a project would affect, either positively or negatively, vulnerability of people and the social, economic and political processes that generate local vulnerability must, therefore, form part of a vulnerability assessment.

A number of agencies have developed practical tools in an effort to analyse opportunities for integrating climate change adaptation into their activities, including the World Bank, DFID, DANIDA and several NGOs. The World Bank has been developing a project screening and design tool called ADAPT (Assessment and Design for Adaptation to Climate Change: A Prototype Tool). Burton and Van Aalst (2004), when initially outlining the tool, advocated a 
routine climate risk management tool similar to environmental impact assessment (EIA), backed up by a knowledge base of available climate information at global, national and subnational levels. The present tool is designed to assist project developers and assessors in (i) identifying the level of climate risk in a project using a simple description of the project and its location, and (ii) finding sources of information on how to minimise this risk. Complementary to this effort is CRiSTAL (Community Risk Screening Tool - Adaptation and Livelihoods), developed by a consortium of NGOs (IISD, IUCN, SEI-US and Intercooperation). Using the Sustainable Livelihoods Framework, CRiSTAL provides an analytical framework for project developers and managers to $(i)$ understand the links between local livelihoods and climate, (ii) assess a project's impact on community-level adaptive capacity, and (iii) make project adjustments to improve a project's impact on adaptive capacity. The tool was field-tested in five countries (Bangladesh, Mali, Nicaragua, Sri Lanka and Tanzania) and results are currently being evaluated.

In the UK, DFID has greatly raised the profile and importance afforded to climate change. A chapter in the recent White Paper reinforced its commitment to screening in accordance with the G8 Gleneagles Plan of Action (DFID, 2006). Using the ORCHID process as a flexible template, DFID is undertaking further pilot climate risk screening in India, China and Kenya. The Danish Ministry of Foreign Affairs (Danida) has established the Climate and Development Action Programme to climate-proof Danish development co-operation, so that their poverty reduction and socio-economic development objectives can be achieved (Danida, 2005). Modelled around the EU Action Plan's four strategic objectives, the Programme encourages the use of Danida's existing development aid procedures and policies, particularly national and Danida environmental assessment frameworks, as a basis for integration (p. 27). Civil society participation, the role of traditional knowledge, and support for the Paris Declaration are emphasised.

Most efforts have, with the possible exception of CRiSTAL, focused on risk reduction and EIA type procedures so far. EIAs, whilst clearly having had considerable positive effects on the way development projects are designed and run, are only as good as their follow-up in practical development work. Challenges persist in ensuring the quality, relevance and independence of EIAs and in implementing their recommendations. One of the criticisms of EIAs is that they often fail to consider local perspectives. This is important for climate risk assessments as well, as risks identified from meteorological records may be different from those that communities perceive as the biggest climate risks, and where mobilising local experiences could be a key asset for identifying relevant indicators and adaptation options. Furthermore, it is clear that different approaches to screening will be necessary in countries with distinct aid modalities, and this will have an important influence on the development of generic tools by the World Bank and OECD as requested in the declarations noted in the earlier section.

Project portfolios are large and diverse. Whilst screenings can be carried out using any combination of the three assessment types identified above, relevant parameters need to be defined in order to provide some structure to the screening process. Apart from finding ways of identifying where climate risks are important, a perhaps equally important test of the tools would be their ability to identify areas and cases where climate risks are of less or no importance, avoiding potentially costly efforts that overstate the importance of climate risks and that could discredit the screening process. In other words, which element(s) of an agency's programming should be screened? Depending on the agency, programmes may be organised in a number of ways, providing a basis for defining the screening parameters:

- Country (e.g., a country strategy in Sri Lanka);

- Geographical region (e.g., co-operation priorities in Central America);

- Sector (e.g., agriculture, business);

- Theme (e.g., education and training); 
- Some combination of the above (e.g., agriculture in sub-Saharan Africa).

The level of evaluation within each of these categories may range from general (i.e., evaluating programme statements) to specific (evaluating projects). If the aim of a screening process is to obtain a broad picture of an agency's overall approach to climate change adaptation, then an evaluation of all programme statements (possibly supplemented with a few project evaluations in each programme, resources permitting) may be most appropriate.

Finally, in screening an agency's project portfolio, the decision will need to be made on whether to focus strictly on vulnerability and adaptation to climate change, on mitigation of greenhouse gas emissions or on both. Some development policies, strategies and projects will address both adaptation and mitigation, whilst others will exclusively address either adaptation or mitigation.

In order to identify the links between a comprehensive adaptation approach and the overarching development approach, analysing how the development priority is linked to climate change can be a good starting point. How does the development priority affect vulnerability to climate change and adaptive capacity? What are the main gaps in knowledge regarding the links described above? An important issue to consider is whether or not current climate stresses are mentioned in programme and project documents and specifically whether or not these documents specify the vulnerability of and adaptation priorities for different regions, countries and sectors (as identified in IPCC reports and National Communications to the UNFCCC). In a comprehensive approach, climate change adaptation needs to become part of the dialogue between development agencies and recipient countries regarding development priorities. In this regard, identifying entry points for enhancing climate change considerations in development programming is important, which involves analysing how climate change can be incorporated into strategic programming areas (e.g., natural resource management, humanitarian assistance, education and training). In order to make such a dialogue possible agency staff need to have a minimum level of awareness and capacity for addressing climate change.

As identified in previous screenings, the awareness of and attention paid to climate change has often been negligible in development agencies. To ensure the screening outputs are integrated into programming considerations, agencies should focus on strengthening institutional links within and outside of the agency during the screening process and followup activities. Within the agency, this would include, embedding the screening study within the institution; involving different departments in the study; and devising a strategy for implementing results of the screening across the agency. The latter would involve the identification of follow-up activities, including a progress review. In addition, sharing experiences and results from screenings with other development agencies and co-ordinating screening outputs with other policy processes, such as those related to the National Adaptation Programmes of Action (NAPAs), the Clean Development Mechanism, the GEF and UNFCCC-related adaptation funds is important.

\section{Conclusions and Next Steps}

This paper is a first attempt at bringing together experiences from recent efforts to screen development policies, projects and programmes with regard to climate change, focusing on scope, results and methods applied. It discusses how screenings can support the mainstreaming of adaptation to climate change into official development assistance. The screenings of development agencies' projects and programmes have shown, first, that climate change was initially almost absent from the agencies' activities. Where mentioned, it was framed as an issue of mitigation and in the domain of environment ministries and departments. Notably, little connection to long-term climate change has been made in areas where climate already poses a clear risk today. Second, since the initial screenings the 
political landscape has changed considerably, based on an increased understanding of the need for mainstreaming and what such mainstreaming entails for development agencies. The reasons for the initial lack of attention may be the dearth of understanding regarding practical links between poverty reduction and adaptation to climate change, and a perception of climate change adaptation as being limited to technological responses to identified changes in climate variables. In this paper we have identified the need for a comprehensive approach to adaptation, that is, for mainstreaming to address a range of stressors and underlying causes of vulnerability, in addition to technological adaptation measures. This has implications for the type of assessment carried out in screenings and the choice of parameters determining its focus. The latter is particularly important because a comprehensive approach to mainstreaming that addresses the underlying causes of vulnerability entails targeting a strategic level at the project and programme design phase, rather than at a reactive level where technological adjustments to projects are made in response to expected climate change. EIAtype climate risk assessments, whilst contributing to mainstreaming, cannot alone effectively achieve comprehensive mainstreaming.

A comprehensive approach to mainstreaming adaptation is relevant to a wide range of activities in development agencies. However, to demonstrate this relevance requires the screenings to be embedded more broadly institutionally than has previously been the case within development agencies, where climate change has been confined as an issue for environmental departments.

We have outlined how development projects may affect the vulnerability of people and communities, and how incorporating climate change into development assistance could reduce vulnerability today and in the future. Portfolio screening per se is no panacea for ensuring adequate attention to adaptation within development co-operation, but could become one of the key elements for developing a more sophisticated understanding of the complex relationships that determine people's vulnerability to climate change. However, its contribution to mainstreaming adaptation into development assistance will depend on a number of factors. Portfolio screening must be seen as a process rather than a product, taking on board lessons not only from the screenings undertaken to date but also from experiences from the use of environmental impacts assessments and other tools, as well as similar processes of mainstreaming crosscutting issues (such as gender) into development. Other conditions for success include an ability to utilise the vast experiences of people, communities and development agencies with past climate variability, to co-ordinate with ongoing processes within the international climate regime (such as NAPAs), and to integrate medium and longterm needs as well as immediate priorities.

\section{Acknowledgements}

An earlier version of this paper was presented at the conference "Climate or Development?", which was organised by the Hamburg Institute of International Economics (Hamburg, Germany, 28-29 October 2005). We thank the participants in this conference, as well as Jörg Balsiger, Timo Menniken, Annett Möhner, Cristina Rumbaitis del Rio and two anonymous reviewers, for their helpful comments. We also thank Kirsten Ulsrud for her help in collecting and analysing relevant literature. RK, SE and LON received financial support from the Norwegian Agency for Development Co-operation (Norad). This paper contributes to the project ADAM (Adaptation and Mitigation Strategies, Supporting European Climate Policy), which is funded by the European Commission under contract number 018476 (GOCE).

\section{Endnotes}

1 Five of the authors of this paper were involved in these screenings (Klein, Eriksen, Næss, Tanner and Robledo).

2 All projects and programmes included in the screening were related to natural resource management and implemented by the Swiss Foundation for Development and Co-operation, Intercooperation. Projects and programmes in the following countries were included: 
Ecuador, Bolivia, Mali, Madagascar, Tunisia, Kyrgyz Republic, Bangladesh, India and Bulgaria.

3 In this declaration, the 15 EU member states, Canada, Iceland, New Zealand, Norway and Switzerland agreed to contribute USD 410 million / EUR 450 million per year by 2005, with this level to be reviewed in 2008 (UNFCCC, 2001).

\section{References}

Adams, A.M., J. Cekan and R. Sauerborn, 1998: Coping with crises in the Sahel. Africa, 68(2), 263-283.

Adger, W. N., Kelly, P. M. and N.H. Ninh (eds.), 2001: Living with Environmental Change: Social Resilience, Adaptation and Vulnerability in Vietnam, Routledge, London, $\mathrm{UK}, 314 \mathrm{pp}$.

Adger, W.N. and P.M. Kelly, 1999: Social vulnerability to climate change and the architecture of entitlements. Mitigation and Adaptation Strategies for Global Change, 4(3-4), 253-266.

Adger, W.N., S. Huq, K. Brown, D. Conway and M. Hulme, 2003: Adaptation to climate change in the developing world. Progress in Development Studies, 3(3), 179-195.

Agrawala, S. and M. Berg, 2002: Development and Climate Change Project: Concept Paper on Scope and Criteria for Case Study Selection. Organisation for Economic Cooperation and Development, Paris, France, 17 pp.

Agrawala, S., 2004a: Adaptation, development assistance and planning: challenges and opportunities. IDS Bulletin, 35(3), 51-53.

Agrawala, S., 2004b: Mainstreaming Adaptation in Development Planning and Assistance: A Joint Project between the OECD Environment and Development Co-operation Directorates. Presentation at UNFCCC Adaptation Workshop, Bonn, Germany, 18 June 2004.

Agrawala, S., A. Möhner, A. Hemp, M. van Aalst, S. Hitz, J. Smith, H. Meena, S.M. Mwakifwamba, T. Hyera and O.U. Mwaipopo, 2003a: Development and Climate Change in Tanzania: Focus on Mount Kilimanjaro. COM/ENV/EPOC/DCD/DAC(2003)5/FINAL, Organisation for Economic Cooperation and Development, Paris, France, 72 pp.

Agrawala, S., A. Möhner, F. Gagnon-Lebrun, W.E. Baethgen, D.L. Martino, E. Lorenzo, M. Hagenstad, J. Smith and M. van Aalst, 2004b: Development and Climate change in Uruguay: Focus on Coastal Zones, Agriculture and Forestry.

COM/ENV/EPOC/DCD/DAC(2004)2/FINAL, Organisation for Economic Cooperation and Development, Paris, France, 72 pp.

Agrawala, S., A. Möhner, M. El Raey, D. Conway, M. van Aalst, M. Hagenstad and J. Smith, 2004a: Development and Climate Change in Egypt: Focus on Coastal Resources and the Nile. COM/ENV/EPOC/DCD/DAC(2004)1/FINAL, Organisation for Economic Co-operation and Development, Paris, France, 68 pp.

Agrawala, S., Ota, T., Ahmed, A.U., Smith, J. and M. van Aalst, 2003b: Development and Climate Change in Bangladesh: Focus on Coastal Flooding and the Sundarbans. COM/ENV/EPOC/DCD/DAC(2003)3/

FINAL, Organisation for Economic Co-operation and Development, Paris, France, 70 
pp.

Agrawala, S., T. Ota, J. Risbey, M. Hagenstad, J. Smith, M. van Aalst, K. Koshy and B. Prasad, 2003c: Development and Climate Change in Fiji: Focus on Coastal Mangroves. COM/ENV/EPOC/DCD/

DAC(2003)4/FINAL, Organisation for Economic Co-operation and Development, Paris, France, 56 pp.

Agrawala, S., V. Raksakulthai, M. van Aalst, P. Larsen, J. Smith and J. Reynolds, 2003d: Development and Climate Change in Nepal: Focus on Water Resources and Hydropower. COM/ENV/EPOC/DCD/DAC (2003)1/FINAL, Organisation for Economic Co-operation and Development, Paris, France, 64 pp.

Burton, I. and M. van Aalst, 1999: Come Hell or High Water: Integrating Climate Change Vulnerability and Adaptation into Bank Work. World Bank, Washington, DC, USA, 60 pp.

Burton, I. and M. van Aalst, 2004a: Vulnerability and adaptation in Bank work: progress and prospects. In: An Adaptation Mosaic: A Sample of the Emerging World Bank Work in Climate Change Adaptation. World Bank, Washington, DC, USA, pp. 41-52.

Burton, I. and M. van Aalst, 2004b: Look Before You Leap: A Risk Management Approach for Incorporating Climate Change Adaptation in World Bank Operations. Final Draft, February 2004. World Bank, Washington, DC, USA, 55 pp.

Burton, I., S. Huq, B. Lim, O. Pilifosova and E.L. Schipper, 2002: From impacts assessment to adaptation priorities: the shaping of adaptation policy. Climate Policy, 2(2-3), 145159.

Commission for Africa. 2005. Our Common Interest: Report of the Commission for Africa. Available at www.commisionforafrica.org

Danida, 2005. Danish Climate and Development Action Programme. Ministry of Foreign Affairs, Denmark.

Davis, D.K., 2006: Neoliberalism, environmentalism, and agricultural restructuring in Morocco. Geographical Journal, 172(2), 88-105.

DFID, 2004. Poverty and Climate Change: Key Sheets 1-13. DFID. Available at www.dfid.gov.uk

DFID, 2006. Eliminating World Poverty: Making Governance Work for the Poor. White Paper on International Development. Department for International Development, London.

EC, 2004: EU Strategy on Climate Change in the Context of Development Cooperation: Action Plan 2004-208. DGE, European Commission, Brussels.

Eriksen, S. and L.O. Næss, 2003: Pro-Poor Climate Adaptation: Norwegian Development Cooperation and Climate Change Adaptation-An Assessment of Issues, Strategies and Potential Entry Points. CICERO Report 2003:2, Centre for International Climate and Environmental Research Oslo, University of Oslo, Norway, viii+75 pp.

Eriksen, S. and P.M. Kelly, 2005: Developing credible vulnerability indicators for policy 
assessment. Mitigation and Adaptation Strategies for Global Change, in press.

G8 Gleneagles Summit, 2005: Gleneagles Plan of Action - Climate Change, Clean Energy and Sustainable Development. Accessed January 9, 2006,

http://www.defra.gov.uk/corporate/international/g8-presidency/pdf/gleneaglesplanofaction. pdf

Gupta, R.K. and I.P. Abrol, 2000: Salinity build-up and changes in the rice-wheat system of the Indo-Gangetic Plains. Experimental Agriculture, 36(2), 273-284.

http://www.oecd.org/dataoecd/44/29/36426943.pdf

Huq, S., A. Rahman, M. Konate, Y. Sokona and H. Reid, 2003: Mainstreaming Adaptation to Climate Change in Least Developed Countries (LDCs). International Institute for Environment and Development, London, UK, $40 \mathrm{pp}$.

Kasparek, M., 2003: Anpassung an den Klimawandel: Ergebnisse eines Screenings der deutschen TZ-Projekte. Deutsche Gesellschaft für Technische Zusammenarbeit, Eschborn, Germany, 17 pp + annexes. (Adaptation to Climate Change: Results of a Screening of German Technical Co-operation Projects, In German.)

Kelly, P.M. and W.N. Adger, 2000: Theory and practice in assessing vulnerability to climate change and facilitating adaptation. Climatic Change, 47(4), 325-352.

Klein, R.J.T., 2001: Adaptation to Climate Change in German Official Development Assistance-An Inventory of Activities and Opportunities, with a Special Focus on Africa. Deutsche Gesellschaft für Technische Zusammenarbeit, Eschborn, Germany, 42 pp.

Klein, R.J.T., 2002: Climate Change, Adaptive Capacity and Sustainable Development. Expert Meeting on Adaptation to Climate Change and Sustainable Development, Organisation for Economic Co-operation and Development, Paris, France, 13-14 March 2002, 8 pp.

Klein, R.J.T., 2003: Adaptation to climate variability and change: what is optimal and appropriate? In: Climate Change in the Mediterranean: Socio-Economic Perspectives of Impacts, Vulnerability and Adaptation, C. Giupponi and M. Schechter (eds.), Edward Elgar, Cheltenham, UK, pp. 32-50.

Klein, R.J.T., E.L.F. Schipper and S. Dessai, 2005: Integrating mitigation and adaptation into climate and development policy: three research questions. Environmental Science and Policy, 8(6), 579-588.

Klein, R.J.T., M. Alam, I. Burton, W.W. Dougherty, K.L. Ebi, M. Fernandes, A. Huber-Lee, A.A. Rahman and C. Swartz, 2006: Application of Environmentally Sound Technologies for Adaptation to Climate Change. Technical Paper FCCC/TP/2006/2, United Nations Framework Convention on Climate Change Secretariat, Bonn, Germany, 107 pp.

Markandya, A. and K. Halsnæs, 2002: Climate Change and Sustainable DevelopmentProspects for Developing Countries. Earthscan, London, UK, xii+291 pp.

McCarthy, J.J., O.F. Canziani, N.A. Leary, D.J. Dokken and K.S.White (eds.), 2001: Climate Change 2001: Impacts, Adaptation and Vulnerability. Contribution of Working Group II to the Third Assessment Report of the Intergovernmental Panel on Climate Change, Cambridge University Press, Cambridge, UK, $\mathrm{x}+1032$ pp. 
Michaelowa, A. and K. Michaelowa, 2005: Climate or Development: Is ODA Diverted from its Original Purpose? Paper presented at the conference "Climate or Development?", Hamburg Institute of International Economics, Hamburg, Germany, 28-29 October $2005,19 \mathrm{pp}$.

Ministry of Foreign Affairs of Denmark, 2005: Danish Climate and Development Action Programme: A Tool Kit for Climate Proofing Danish Development Cooperation.

DANIDA, Ministry of Foreign Affairs of Denmark, Copenhagen, Denmark, 51 pp.

Mitchell, T. and T.M. Tanner, 2006: Overcoming the Challenges: Barriers and Opportunities to Mainstreaming Climate Change Adaptation. Tearfund, Teddington, UK.

O'Brien, K, S. Eriksen, A. Schjolden and L. Nygaard, 2004: What's in a Word? Conflicting Interpretations of Vulnerability in Climate Change Research. CICERO Working Paper 2004:4, Centre for International Climate and Environmental Research Oslo, University of Oslo, Norway, iii+16 pp.

Organisation for Economic Co-operation and Development (OECD). 2006: Declaration on Integrating Climate Change Adaptation into Development Co-operation Adopted by Development and Environment Ministers of OECD Member Countries. 4 April 2006. Accessed January 9, 2006:

Orindi, V.A. and S. Eriksen, 2005: Mainstreaming Adaptation to Climate Change in the Development Process in Uganda. Ecopolicy Series 15, African Centre for Technology Studies, Kenya, Nairobi, vii+29 pp.

Robledo, C. and C. Forner, 2005: Adaptation of Forest Ecosystems and the Forest Sector to Climate Change. Forests and Climate Change Working Paper 2, Food and Agricultural Organisation, Rome, Italy, viii+88 pp.

Robledo, C. et al., 2006: Understanding Linkages between Development Cooperation in Natural Resource Management and Vulnerability to Climate Change and Climate Variability. Swiss Agency for Development and Co-operation, Berne, Switzerland, in prep.

SDC, 2005: Addressing Climate Change through Development Cooperation: An Orientation on Climate Change Issues in the Fields of Natural Resource Management, Livelihoods and Food Security. Swiss Agency for Development and Co-operation, Berne, Switzerland, $15 \mathrm{pp}$.

Smith, J.B., R.J.T. Klein and S. Huq, 2003: Climate Change, Adaptive Capacity and Development. Imperial College Press, London, UK, viii+347 pp.

Smithers, J. and B. Smit, 1997: Human adaptation to climatic variability and change. Global Environmental Change, 7(2), 129-146.

Sperling, F. (ed.), 2003: Poverty and Climate Change-Reducing the Vulnerability of the Poor through Adaptation. AfDB, ADB, DFID, EC DG Development, BMZ, DGIS, OECD, UNDP, UNEP and the World Bank, Washington, DC, USA, xii+43 pp.

Stern, N. 2007: The Economics of Climate Change: The Stern Review. Cambridge University Press, Cambridge.

Tanner, T.M., Conway, D., Hassan, A., Alam, M., Islam, N., Ahmed A.U. and Mechler, R, 
2007: ORCHID: Piloting Climate Risk Screening in DFID Bangladesh. Research Report. Institute of Development Studies, Sussex, UK.

Ulsrud, K. and S. Eriksen, 2006: Summary of the Norad/GECHS workshop on climate change and development, Oslo, January 9-10 2006. GECHS project and Department of Sociology and Human Geography, University of Oslo. Accessed 10 December 2006, www.gechs.org. 25 pp.

\section{United Nations Framework Convention on Climate Change (UNFCCC), 2005}

United Nations Framework Convention on Climate Change (UNFCCC). 2001:

Implementation of the Buenos Aires Plan of Action: Statements made in connection with the approval of The Bonn Agreements on the implementation of the Buenos Aires Plan of Action (decision 5/CP.6). Note by the secretariat. FCCC/CP/2001/MISC.4.

Willows, R.I. and Connell, R.K. (Eds.), 2003: Climate Adaptation: Risk, Uncertainty and Decision-Making. UKCIP Technical Report. UK Climate Impacts Programme, Oxford, UK, vii+154 pp.

World Bank 2006: Clean Energy and Development: Towards an Investment Framework. ESSD-VP/I-VP. April 5, 2006. World Bank, Washington, DC, USA, x+38 pp.

Zhou, D., Gong, H., Luan, Z., Hu, J., and F. Wu, 2006: Spatial pattern of water controlled wetland communities on the Sanjiang Floodplain, Northeast China. Community Ecology, 7(2), 223-234. 